\title{
Addressing a Blind Spot: Altruistic Fear and Religious Bias Motivated Victimization
}

\author{
Emily N. Hawkins \\ West Virginia University, enh0005@mix.wvu.edu
}

Follow this and additional works at: https://researchrepository.wvu.edu/etd

Part of the Sociology of Religion Commons

\section{Recommended Citation}

Hawkins, Emily N., "Addressing a Blind Spot: Altruistic Fear and Religious Bias Motivated Victimization" (2021). Graduate Theses, Dissertations, and Problem Reports. 8152.

https://researchrepository.wvu.edu/etd/8152

This Thesis is protected by copyright and/or related rights. It has been brought to you by the The Research Repository @ WVU with permission from the rights-holder(s). You are free to use this Thesis in any way that is permitted by the copyright and related rights legislation that applies to your use. For other uses you must obtain permission from the rights-holder(s) directly, unless additional rights are indicated by a Creative Commons license in the record and/ or on the work itself. This Thesis has been accepted for inclusion in WVU Graduate Theses, Dissertations, and Problem Reports collection by an authorized administrator of The Research Repository @ WVU. For more information, please contact researchrepository@mail.wvu.edu. 
Addressing a Blind Spot: Altruistic Fear and Religious Bias Motivated Victimization

Emily N. Hawkins, MPA

\author{
A thesis submitted to the \\ Eberly College of Arts and Sciences \\ at West Virginia University \\ in partial fulfillment of the requirements for the degree of \\ Master of Arts in Sociology
}

Christopher Scheitle, Ph.D., Chair
Corey Colyer, Ph.D.
Katie Corcoran, Ph.D.
Department of Sociology and Anthropology

Morgantown, West Virginia

2020

Keywords: religion, criminology, hate crime, fear of crime, religious bias, altruistic fear Copyright 2020 Emily Hawkins 


\begin{abstract}
Addressing a Blind Spot: Altruistic Fear and Religious Bias Motivated Victimization

Emily Hawkins
\end{abstract}

Fear of victimization is different than actual victimization but has real consequences for individuals' behaviors and attitudes. Research on fear of victimization in the United States has typically emphasized individuals' own fears of experiencing violent, sexual, and property crimes. Yet, some studies suggest that fear of crime for other people whose safety one values significant others, friends, and children - or altruistic fear is more common and often more intense than one's personal fear of victimization. While some literature exists on the prevalence of altruistic fear in American households, little is known about altruistic fears specifically rooted in the fear of victimization based on a close family member's or friend's religious identity. Additionally, some studies suggest that there is a gendered aspect to altruistic fear, where men and women worry and express their fear for loved ones differently. It is likely that these gendered differences manifest in different ways depending on religious tradition. This paper aims to extend the literature on altruistic fear by applying this phenomenon to hate crime victimization, more specifically the fear of victimization based on religious identity. 


\section{Table of Contents}

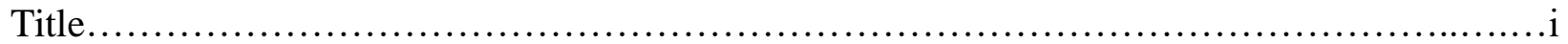

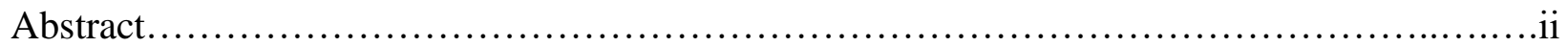

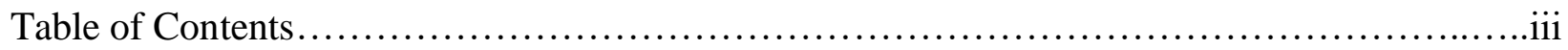

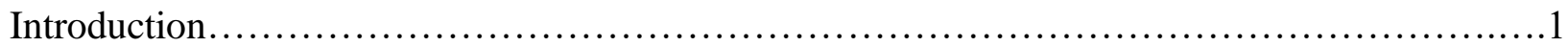

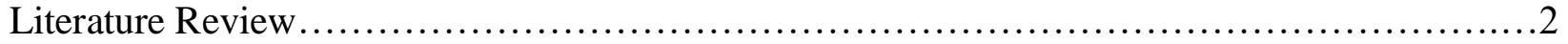

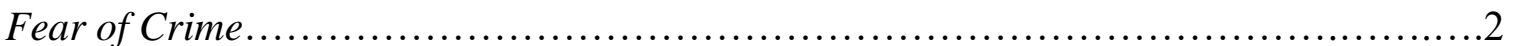

Altruistic Fear.......................................................................

Mechanisms of Fear............................................................... 5

Fear of Hate Crime ..................................................................

Religious Victimization in the U.S............................................. 10

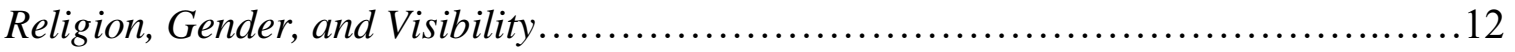

Expectations..................................................................... 15

Data and Measures................................................................... 16

Dependent Variable ...............................................................

Independent Variables........................................................ 18

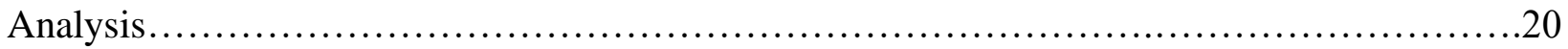

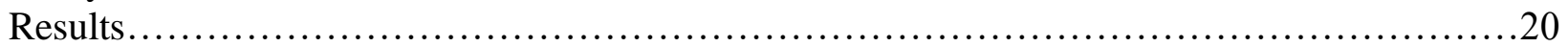

Table 1: Descriptive statistics table of the percent of respondents reporting altruistic fear, by religious tradition ...................................................... 21

Table 2: Descriptive statistics table of the percent of respondents reporting knowing someone who has been victimized, by religious tradition ..............................22 Table 3: Descriptive statistics table of the altruistic fear response percentage by religious tradition and gender..........................................................22

Table 4: Correlation table displaying zero-order correlation coefficients among the measured variables.............................................................23

Table 5: Table displaying all logit regression models predicting altruistic fear...........23

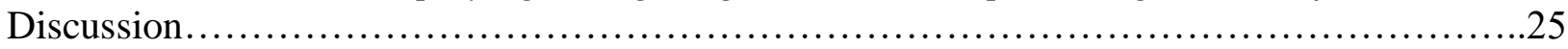

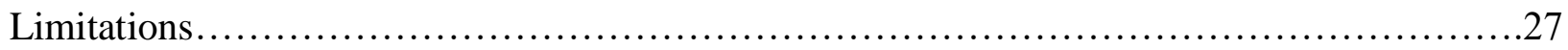

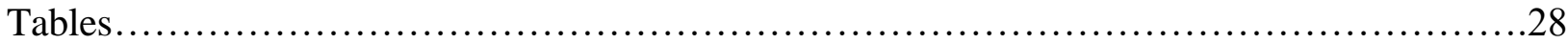

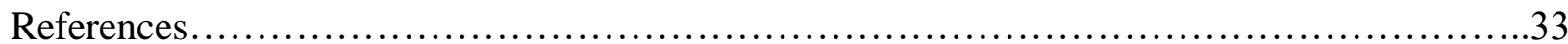




\section{Introduction}

At its core, altruistic fear is a phenomenon that describes an individual's fear of crime as it relates to the safety and well-being of others, mostly those closest to them. Previous studies in this area indicate that the issue of altruistic fear may be more prevalent and more of a problem than personal fear (Warr 1992; 1994; 2000). Yet, while the fear of victimization and fear of crime literature is robust, there is still little known about altruistic fear, despite its potential to have more intense effects on the feelings and behavior of the individual than personal fear of victimization (Warr 1992). And while the phenomenon of altruistic fear does not seem to be limited to specific types of crime (e.g. property crime, sexual assault, or violence), previous research has not examined altruistic fear in relation to religious-biased motivated hate crimes or even hate crimes more generally.

In terms of fear of victimization motivated by bias, there is substantial research, mostly in the context of race, gender, and sexual orientation biases (Craig 1999; Pain 2000; Herek, et al. 1999). There is much less research examining fear of victimization based on religious biases and no research examining this issue and its relation to altruistic fear (Biles, et al. 2002; Byers 2006). In short, the study presented here is interested in examining whether the phenomenon of altruistic fear can be observed or extended to the fear of religious victimization and thus, to hate crime and bias-motivated victimization as a whole. Additionally, this study aims to assess how altruistic fears of religious victimization differs by religious tradition and how those differences might be moderated by gender.

I hypothesize that altruistic fear will be more of an issue for individuals that identify with highly visible and highly stigmatized (or least liked) minority religious groups over those that are less visible and less stigmatized. Americans tend to express more positive feelings towards 
certain religious groups over others (Pew Research Center 2017) and certain religious groups are more vulnerable or more likely to be victimized for their religion over other religions. This could be due to negative connotations and bias towards the religious itself, along with other identifiers such as religious visibility (dress, tattoos, jewelry, hair styling, etc.) or perceived ethnicity. Because of this, I argue that Jews, Muslims, and Hindus in this study will be more likely to experience feelings of altruistic fear over all other religious groups.

Previous studies of altruistic fear find that there is a clear gendered aspect to this phenomenon, as women and men typically experience feelings of altruistic fear differently and for different people closest to them. And since religious identity tends to be expressed and practiced differently in some religious traditions by gender, I hypothesize that gender will moderate the effect of religious tradition, but not the same across religious tradition. For example, I would argue that Muslim men are more likely to experience feelings of altruistic fear than Muslim women, while the opposite effect would exist for Jews, where Jewish women are more likely to experience feelings of altruistic fear than Jewish men. I also hypothesize that nonreligious identifying people (No religion, Atheists, and Agnostics) and majority religious groups (All denominations of Christianity) will be less likely than other religious groups to experience feelings of altruistic fear based on religious victimization. Also, in accordance with past research that indicates differences in fear of crime across various groups, I hypothesize that ethnic and racial minorities within each religious tradition will be more likely to experience feelings of altruistic fear, as well as those with lower incomes and lower levels of education.

\section{Fear of Crime}

While actual victimization is the most obvious and visible product of hate crime, the fear or concern of potential victimization can also be distressing and have potentially damaging 
effects on individuals and communities. The fear of crime literature is extensive, but much of the research focuses on personal fears of being violently victimized, property crime, and sexual assault victimization (Cook, et al. 2011; Gainey, et al. 2011; May 2001; Singer, et al. 2019). While incidents of actual violent victimization are quite rare (O’Brien 1995), fear of victimization is quite common. About $40 \%$ of Americans reported that they are afraid to walk alone at night in their own neighborhoods, while more than half agree that being a victim of a crime is something that they "personally worry about" (Maguire and Pastore 1997; Warr 1994). These fears of victimization result in attitudinal and behavioral changes in the individual such as regularly engaging in safety precautions - staying home at night, not traveling alone, avoiding certain areas, and carrying protective equipment in case of a violent incident (Warr 1994). Additionally, previous social science research indicates that personal fears of victimization are more common in some groups compared to others - women fear crime more than men, the elderly more than younger people, African-Americans more than whites, as well as those with lower incomes and less years of education than others (Ferraro 1995). Overall, social scientists have studied the prevalence and behavioral consequences of fear of personal victimization for years, yet the data and research examining both personal and altruistic fears of victimization based on religious identity in the U.S. is severely lacking.

\section{Altruistic Fear}

While sociologists have long studied personal fear of crime and victimization, only a few researchers have examined the issue of altruistic fear, a phenomenon where an individual fears that a significant person close to them will be the object of crime or victimization (Warr 1992). While this phenomenon is understudied in comparison to personal fear, some studies suggest that altruistic fear is actually more common and provokes more intense feelings, emotions, and 
attitudinal and behavior changes than personal fears of victimization (Warr 2000). Most individuals probably have one or more persons in their lives whose safety and protection are a significant concern to them. Altruistic fears of victimization in the typical American household are likely to exist in parental-child bonds, as well as bonds between married couples (Sweet and Bumpass 1990; Jenkins 1992). While altruistic fears can extend beyond one's household, the immediate family and close relational bonds are logical points of inquiry into researching and understanding the prevalence of altruistic fear (Warr 2000).

The few studies of altruistic fear that have been done have tended to highlight the significant influence of gender on the feelings and expression of altruistic fear. For example, men are less likely than women to experience feelings of personal fear of victimization (despite higher rates of victimization), yet may be more concerned with the safety of their partners and children. This concern can result in exhibiting attitudes and behaviors that ensure the safety of their children and contribute to their identity as the male protector of their family household (Rader, et al. 2009; Trickett 2009). While men might be perceived as more able to readily protect themselves in the event of a violent incident, they are much more likely to be victims of violence than women (Maguire and Pastore 1997). In their 2000 study, Warr and Ellison find that within the context of spousal relationships in the American households, husbands are more likely to worry about the safety of their wives than the reverse (p.574). While some wives do fear for the safety of their husbands in this study, their results align with previous research that indicate that women are often more concerned with their own safety, much more than men. In the context of parent-child relationships, mothers were slightly more likely than fathers to express fear for their children, while both mothers and fathers tend to display greater fear of victimization for their daughters than sons (p.575). Because of this gender pattern in the altruistic fear research, I expect 
that overall men will have more altruistic fear than women. Another study suggests that due to women reporting more feelings of altruism and empathy for others and because of the socialization of women as "caretakers and nurturers", that women may shoulder more "emotional work" and therefore have more fear for others than men do (Snedker 2006). Yet, men are often designated as "protectors" of their loved ones and often report less feelings of personal fear than women and more of a social obligation and responsibility for the protection and safety of those closest to them. Due to the often-gendered nature of religious expression and visibility in some religious groups, it would be important to know whether these previously discovered gendered differences in altruistic fear will manifest similarly when looking specifically at victimization motivated by religious bias. I hypothesize that the combination of differences in religious visibility and perceived vulnerability across groups can cause the opposite effect of fear to occur (women more fearful than men) for certain religious groups.

\section{Mechanisms of Fear}

Because of the obviously gendered nature and expression of altruistic fear, it is important to understand the mechanisms that cause altruistic fear and why these differences arise between groups. The demographic differences in fear of crime (for oneself) is often chalked up to one's perceived risk of victimization and vulnerability. As mentioned, some groups experience fear of crime more than others and some people fear victimization for their loved ones more than others. In his study, Drakulich (2014) explores the potential sources of altruistic fear. His results indicate that individuals' fears for others is often rooted in their own experiences with personal victimization and their evaluations of the local danger posed by crime and results in behavior and attitudinal changes such as community withdrawal and protective measures.

\section{Risk Perception}


In another study examining altruistic fear in men, Trickett (2009) finds that men's altruistic fears, often for their children and significant others, was rooted in their inability to control the risks for their loved ones and the perceived vulnerability of the people closest to them. Trickett notes that this desire to take control of potential harm from a loved one could be rooted in the male individual's internalized identity as male protectors of the family and highly responsible for the safety of others - especially of those perceived to be most vulnerable. Additionally, she finds that these altruistic fears exhibited in men change throughout the life course and often one's ability to protect their household is a reflection of their male identities and roles as husbands or fathers (Trickett, p. 103). Overall, the results of this study align with some of the previous research on perceived risk and vulnerability and how it relates to fear of crime. Trickett's study suggests that altruistic fears are not much different in their root causes than personal fears of crime - as they can both be driven by risk perception of the potential victim (oneself or others) and that fear of crime can be a social attitude and not just concerned with the individual. In their work, Thompson and Dean, define two different conceptions of risk (1996). One is probabilistic and the other is contextualist. Briefly defined, risk from a probabilistic standpoint is solely a matter of the probability of the event and its consequences. Conversely, the contextualist perspective of risk is more complex as it aims to question public understanding and response, control, cultural/societal implications of being 'at risk', trusting-ness and blame. In this perspective, risk will likely be associated with concepts such as voluntariness, familiarity/unfamiliarity, and societal or personal danger (Thompson and Dean 1996). This 'contextualistic' risk perception literature leads us to more causal understanding of fear of crime by linking the individual to more measurable concepts of risk such as likelihood of victimization, sense of control, and the resonance and impact of the event. The resonance and impact or 'social 
influence' portion plays a key role and often leads to discussions of morality and blame (Sparks 1992), which we often see when acts of religious-bias motivated hate crime become well known and newsworthy.

\section{Vulnerability}

The idea of perceived vulnerability to victimization is a key theme in much of the fear of crime literature (Hale 1996; Killias 1990) and three dimensions of vulnerability have arisen out of that research: exposure to risk, the anticipation of serious consequences, and the loss of control (lack of effective defense, protective measures and possibilities of escape) (Killias 1990, p.89-91). These are all necessary to produce fear and they are associated with physical, social, and situational aspects of vulnerability. Because of the individual differences in perceived vulnerability and ability to control the situation through defense, escape, and protection, this perspective could explain the differences in fearfulness of crime between groups - i.e. why women are more worrisome and fearful of personal crime than men, despite men having higher frequencies of victimization (Jackson 2007). This is closely related to Warr's research above which detailed the gendered differences in both personal and altruistic fear, which he phrased as “differential sensitivity to risk” (1987). Some reasons to explain frequent worry could be one's ability to fend off an attack, assessment of personal consequences of being victimized, judgements of control over the risk, perceptions of likelihood of being victimized, and beliefs about relative-risk levels (Jackson 2007). Vulnerability is different from risk perception in that it is related to something about the individual/potential victim, while perceived risk analyzes the external context/perpetrator and control over the situation. 


\section{Fear of Hate Crime}

The literature on altruistic fear of crime has not addressed the fear of hate or biasmotivated crimes specifically, especially in relation to the fear of religious-bias motivated hate crimes. Some past research indicates that the fear of becoming a victim of a hate crime does differ by ethnic background (Levin, et al. 2001; Chongatera 2013), race (Craig 1999; Lyons 2008; Perry 2002; Zaykowski 2010), sexual orientation (Stotzer 2010; Fox, et al. 2018), gender (Javaid 2019; Dunbar 2006), and immigrant status (Wu, et al. 2014) and is often related to past experiences of being a victim of anti-group sentiments and hate. Additionally, many of these studies indicate that visibility as a minority group contributes to the fear of hate crime, as well as becoming an actual victim. In terms of the fear of religious-biased motivated hate crime, the literature is quite sparse. Past studies tend to focus on specific religious groups and actual victimization rather than the fear of victimization, with the most recent and most prevalent focusing on post-9/11 anti-Muslim hate crimes (Byers, et al. 2007; Disha, et al. 2011). It is clear that more research needs to be done on the examination of fear of hate crime (personal and altruistic), particularly related to religious-bias motivated hate crimes.

In relation to altruistic fear and hate crimes, some studies have discussed the idea of vicarious (or indirect) victimization - which simply refers to the fear of the crime or the potential for risk one has, while not necessarily being directly victimized. Social scientists, scholars, and policy-makers have long referred to bias-motivated hate crimes as crimes meant to "send a message" (McDevitt, et al. 2002), yet the actual attestation to the idea that those beyond the immediate victims are affected is still understudied and undertested in bias-motivated research. The 'message' sent by the perpetrator is meant to state the individual's identity as offensive and worthy of punishment with violence or intimidation (Ardley 2005). Actual incidents of 
victimization, especially in violent crimes, are known to illicit reactions of shock, anger, fear, vulnerability, inferiority, and normalization of violence of those directly affected (Garnets, et al., 1992; Lawrence 1999), but studies have suggested that vicarious victims of hate crimes illicit the same or a similar complex syndrome of reactions (Perry et al. 2003; 2012). In this study, their findings suggest that the "awareness of violence directed toward another within an identifiable target group yields strikingly similar patterns of emotional and behavioral responses of vicarious victims" (2012: p.57). Additionally, their findings suggest that both proximal and vicarious victims also engage in behavioral and attitudinal changes, such as shifting patterns of social interaction. These shifts in the actions of the victims' groups can be the result of real or perceived risk of victimization. Applying this understanding of in terrorem effects of hate crime victimization could prove beneficial in deepening our knowledge of religion-related victimization in the United States. Not only do these indirect effects have real responses by distal victims but hate crimes and the potential for hate crimes to occur can provoke retaliation and communal tension (Iganski 2001), which has been demonstrated in reactions to racial/ethnic hate crimes in the United States. Iganski also outlines the "waves" of harm generated by hate crimes the initial victim is located in the center, while waves of harm move towards the initial victim's 'group' in the neighborhood (or family unit), to the initial victim's 'group' beyond the neighborhood, next into other targeted communities, and eventually effecting social norms and values. This wave model is especially useful in understanding the in terrorem effects of actual hate crime victimization, and it could also be applied to better understand fears and concerns of religious victimization. In both Perry's theory of in terrorem effects of hate crime and Iganski's "wave" model of hate crime, it is clear that those with the closest relationships to the initial victim (family, friends, immediate community members) and those within the larger 
'community' that bears the same identity as the victim can have intense responses and reactions to hate crime victimization Additionally, there is no empirical data on how these theories and models apply specifically to religion-based hate crime victimization.

While altruistic fears of victimization and vicarious victimization seem quite similar, there are differences in these phenomena that should be noted for the purposes of this thesis. Firstly, the vicarious victimization model is primarily concerned with the perceived risk and fear of victimization that individuals have for themselves as a result of actual victimization of others. This suggests that while some people have not been personally victimized, they may still have felt indirectly victimized through the victimization of those they have close relationships (family, friends, co-workers, group members) with or even through the exposure of publicized crime incidents in the media (Skogan and Maxfield, 1981; Ferraro, 1995). And while it is termed "vicarious victimization" - this idea is still attesting to one's awareness of potential crime victimization, and thus fear, rather than actual incidents of victimization. On the other hand, the altruistic fear of victimization model is primarily concerned with the perceived risk and fear of victimization an individual has for others, most likely their loved ones and closest relations. Both are categories of interpreting a perceived risk of victimization that can result in behavior and attitudinal changes of the individual, but the object of fear is quite different as one concerns fear for oneself and another is concerned with the fear for others.

\section{Religious Victimization in the U.S.}

Despite the increased media attention on religious hate crime incidents, little is actually known about the true depths of religious victimization in the United States. As previously mentioned, the majority of hate crime and bias-motivated victimization research centers on racial and ethnic victimization and sexual orientation and gender, largely because these categories 
comprise the biggest proportion of hate crime incidents in the United States. But with the recent violent anti-religious incidents such as the 2012 mass shooting at a Sikh temple in Wisconsin (Soni 2013), the 2015 shooting of three young Muslims in Chapel Hill, North Carolina (Ahmed 2015), or the Pittsburgh synagogue massacre, it is clear that minority religious groups are actual targets and victims of violent, hate-motivated incidents in this country. Additionally, racial or ethnic groups that are perceived as being associated with certain religious minority groups have also reported victimization due to this proximity to a religious tradition (Disha 2005; Disha 2011; Hendricks 2007; Iwama 2018). Religious victimization is not limited to minority religious groups, as Christians in the United States have also been targeted in hate crime incidents (Scheitle 2018; Walfield 2017). While religious victimization may not be as pervasive as other forms of bias-motivated victimization, the increased attention on violent hate crimes motivated by religious bias in the past decade is concerning and severely understudied. Although the motivations for and fears of victimization may differ by religious tradition, it's clear that certain religious groups are targets for hate (Byers et al. 2002, Abu-Ras, et al. 2009; Walfield 2017). The more detailed research on religious victimization and persecution that does exist hails from countries other than the United States (Grim and Finke 2007; Chongatera 2013), making research on this subject apt for American social scientists studying religion and hate crimes.

As mentioned, there is not much data that details religious victimization in the United States and there could be various explanations for the lack of information. First, bias-motivated hate crime categorization and reporting has its limitations and actual victimization reports could not be accurate and indicative of the true depth of bias-motivated incidents. In their study, Scheitle and Hartmann (2016) find that religion-rated crimes account for 10-20 percent of all hate crimes, according to reports by the Uniform Crime Reports (UCR) and National Crime 
Victimization Survey (NCVS). Additionally, while the UCR reports consistently declining totals for hate crimes, religious-biased motivated or otherwise, the NCVS does not report the same steady decline. This conflicting information about the nature and trends of religion-related hate crimes in the United States makes it difficult to accurately measure the issue. Another problem with understanding religious victimization in the United States is the complex nature of categorizing and defining hate crimes (Messner 2004; Zaykowski 2010; Gladfelter et al. 2017). Measuring and defining motivation in hate crime incidents can prove difficult, and often hatemotivated biases can intersect and overlap. For example, perceived religious identity and ethnic/racial identity can both be motivators for perpetuating a violent hate crime, or one of these identities can be perceived as the other (Morsch 1991; Green, et al. 2001). Additionally, hate crimes are defined as violent acts entirely motivated by animus, along with including any trace of hate motivating the selection of targets (Green, et al. 2001). Although, there are variations to the definition of what constitutes a hate crime (such as whether victims must be a minority/of a subordinate group), it's clear that the process of discerning motive is difficult. Relying on spoken epithets, a perpetrator's history of intolerance and hatred, or any other circumstantial evidence of hate has proven difficult to establish empirical criteria for discerning motivation in hate crimes.

\section{Religion, Gender, and Visibility}

As previously mentioned, many elements of the mechanisms of fear are the perceived risk and perceived vulnerability of the individual, which can be closely related to one's visibility as a potential target. While religious visibility can present itself differently or not at all for some religious traditions, in the context of this paper, there are a few indicators of visibility, and thus, perceived risk of the individual. Some indicators of religious visibility include public association with one's religion, public acts of prayer, reading religious scripture in public, wearing religious 
head coverings, jewelry, or other forms of clothing and accessories, and displaying religious symbols on the exterior of one's home or property. This includes more obvious examples of religious visibility such as a Muslim woman wearing hijab or the Islamic headscarf, abaya (long, loose dress), or even niqab (face covering), Muslim men donning kufi or taqiyah (head cap) and thobe (long dress) or practicing lihyah (keeping the beard long). Or Orthodox Jewish men wearing the yarmulke or kippah (head cap) along with long, black robes and beards, or Orthodox Jewish women veiling with a tichel (scarf) or sheitel (wig) and modest clothing. Also, some Christian traditions such as Anabaptists, Quakers, and some Methodist denominations, practice the wearing of plain dress, where adherents wear clothes of traditional, modest design, sturdy fabric, and conservative cut. This can include long, plain dresses that cover the arms and legs and bonnets for women, while men might wear some sort of hat, suspenders, and plain clothing. Additionally, some women adherents to other Christian traditions, such as Eastern Orthodox, might also dress modestly and cover their hair. Also, while not solely a religious symbol, some adherents to Hinduism and Jainism might don a bindi or small, usually red, dot on the center of the forehead. A marker of Sikh faith could be a dastar or turban, required for men and optional for Sikh women, that covers the entire hair and sits on top of the head. Some other, less obvious examples of faith indicators can include cross or crucifix, wearing of the Star of David, or Arabic/Islamic writing on one's person or property. While not all followers of these faith traditions might not practice these forms of dress or expression, these are important measures of visibility to consider - especially considering the differences in expression and visibility between genders and their perceived risk to victimization based on these markers. Because of the unique combination of religious visibility and identifying with a minority religious tradition, I hypothesize that certain groups will experience fearfulness more than others. Specifically, that "visible" religious minorities, such as 
Muslims, Jews, and Hindus will be more fearful for themselves and those close to them. For example, while Atheists are also stigmatized for their beliefs, they are also quite "invisible", which may result in less victimization and feelings of fearfulness for oneself and others.

In the United States and other Western societies, religious visibility has put some groups at risk for victimization more than others. Since 9/11, there's been numerous accounts of visible Muslims and those associated with Islam, being victimized through discrimination and harassment due to their religious identity. While Western Muslim women often wear hijab specifically to identify themselves as Muslim to others, non-Muslim and Muslim alike, some have indicated the fear associated with immediate identification with their religion. After 9/11 the hijab seemed to have the stereotype of both oppressive to women and an object of threat to outsiders. Haddad notes that this harassment limited freedoms and the women's anonymity and many women stayed home to avoid public catcalls of "I hate you," "Go home," "America is for Americans," and "Death to Muslims" (Haddad 2007, p.263). This heightened criticism on the veiled Muslim women led to many women removing their hijab, wearing it only in certain settings, or just limiting their time in public (p. 262). Also, Muslim men have had to alter their visibility to avoid potential incidents of harassment. In a 2018 qualitative study, Muslim participants indicated that the violent, terrorist identity has been applied mostly to Muslim men so any visible indicator of being Muslim (thobe, kufi, full beard) could lead to greater harassment, one man indicated that although he saw it going against his beliefs, he made sure that his beard was "shaved and he was groomed" before heading to the airport (Naderi 2018, p. 47). Yet, Muslim men felt they had more freedom in being able to alter their appearance or actions than Muslim women. There is much less, if any, research on other visible religious minorities and the fears of harassment and discrimination based on their religious identity. More 
research should be done on these groups, but the lived experiences of Muslims, Orthodox Jews, and Sikhs in Western societies can help us understand the role that visibility of one's faith plays in perceived risk of victimization and actual victimization.

\section{Expectations}

Based on the research detailed above, I will identify multiple expectations related to altruistic fear and religious victimization. First, I expect that, overall, men will be more likely than women to report having feelings of altruistic fear, specifically related to the fear of religious victimization. I do not think this effect will be consistent across religious traditions, though, due to differences in religious visibility and expression by gender. Because of this, I have additional hypotheses related to altruistic fear and how specific religious traditions might be affected by gender. Next, I expect that certain religious groups will report experiencing feelings of altruistic

fear more than others. This could be due to negative attitudes and stigmatizations towards certain religious identities in the U.S.

Hypothesis 1: Overall, men will report experiencing more altruistic fear of religious victimization than women.

Hypothesis 2: Individuals that identify with certain minority religious groups will report experiencing more altruistic fear than majority or non-religious identifying groups. Jewish, Muslim, Hindu, and Buddhist respondents will report having more altruistic fear than Christians, Atheists, Agnostics, and other religious groups.

Hypothesis 3: Individuals that identify as Christian, Atheist, or Agnostic will be less likely than other religiously-identifying people to report feelings of altruistic fear related to religious victimization.

Next, I hypothesize that minority religious groups in which women tend to be more religiously visible than men will result in men reporting more altruistic fear than women. On the other hand, 
religious groups where men tend to be more religiously visible than women will have the same effect - women will report having more altruistic fear than men.

Hypothesis 4: Muslim men will report having more altruistic fear than Muslim women.

Hypothesis 5: Jewish women will report having more altruistic fear than Jewish men.

While sparse, the research on religious victimization has tended to focus on individual accounts of actual victimization and the prevalence of the issue. Also, the fear of crime literature tends to relate to personal fear of certain crimes such as property crime or assault but does not address the issue of hate crime victimization, especially religious-bias based victimization. While literature on vicarious victimization has looked at hate crime and its broader impacts, little is known about the fear of hate crime victimization for those closest (spouses, children, close friends, etc.) to the individual. This research paper and design aims to address religious victimization through the lens of altruistic fear to determine the differences in fear between religious traditions and gender.

\section{Data and Measures}

Data for this study come from the 2019 Religion-Related Bias and Victimization Study, which was supported by a National Science Foundation grant. The larger study consists of a national survey and follow-up semi-structured interviews with survey respondents. This study focuses on the survey data. The survey for the project was fielded by the survey firm Gallup, Inc. using subjects from its Gallup Panel. Participants for the Gallup Panel, a probability-based national representative panel of U.S. adults, were recruited into the panel using dual frame random-digit-dialing and address-based sampling. All panel members have a known probability of selection into the Gallup Panel, and results can be projected to the entire population. 
Gallup drew a stratified sample of panel members, taking into account demographics correlated to response rates and respondents were selected within each stratum. The response rate for this survey was $40-45 \%$ with 4,774 completed surveys.

Additionally, certain religious groups were oversampled due to being minority groups with fewer members. There were 393 completed interviews for people who are Jewish, 190 from Muslim respondents, 182 from Buddhist respondents, and 55 from people who are Hindu. Due to the extremely small number of people who are Sikh, there were only 25 completed interviews for this group. Lastly, there were 1722 Christian, 1865 with no religious affiliation and 250 other.

\section{Dependent Variable}

Altruistic fear of religious victimization. This variable is the focal point of this paper and the main variable of interest. This variable measures respondents' fears of someone they know being victimized based on their religious identity were measured using the following question:

"Regardless of whether it has happened in the past, how concerned are you that someone you know personally will be threatened, harassed, or violently attacked because of their religion?" The three possible responses offered were: (1) Very concerned, (2) Somewhat concerned, and (3) Not at all concerned.

For this study, I'm most interested in whether respondents have any fear or concern present for people that they know personally, therefore I created a dichotomous outcome for my analysis where 0 equals "not at all concerned" and 1 equals "at least some concern present", and includes responses of either very concerned or somewhat concerned.

Independent Variables

Actual victimization of others. The survey asked respondents the following question: "Not counting yourself, how many people do you know personally who have been threatened, 
harassed, or violently attacked because of their religion?" Possible response selections include (1) None, (2) One, (3) Two or three, (4) Four or more. Research suggests that past experience with victimization, whether your own or those around you, can indicate future changes in attitudes and behaviors, as well as fear of future victimization.

Actual personal victimization. Respondents' personal accounts of their own victimization based on religious identity were measured using the following series of prompts and responses: "Since you reached age 16, how often do you suspect you have experienced the following kinds of incidents because of your religion?" Responses to the particular events included (1) never, (2) once, and (3) twice or more. The possible harassment/victimization incidents include: (a) Had verbal insults directed at you, (b) Been threatened with physical violence, (c) Had your personal property damaged or destroyed, (d) Been chased or followed, (e) Been physically assaulted, (f) Been harassed by police, (g) Had your home vandalized. Since I am not necessarily interested in the different types of victimization experience, but rather the mere presence of a victimization event, these responses were coded into a dichotomous outcome as well. In this case, 0 equals "no incident of harassment experienced" and 1 equals "at least one incident of harassment experienced."

Personal fear of victimization. Respondents' fears of personal victimization based on their religious identity were measured using the following series of prompts and responses: "Regardless of whether these incidents have happened to you in the past, how concerned are you that these things could happen because of your religion?" Responses to the particular events included (1) never, (2) once, and (3) twice or more. The possible harassment/victimization incidents include: (a) Had verbal insults directed at you, (b) Been threatened with physical violence, (c) Had your personal property damaged or destroyed, (d) Been chased or followed, (e) 
Been physically assaulted, (f) Been harassed by police, (g) Had your home vandalized. I am just concerned with the presence of fear of these harassment events occurring, so again, I recoded the variables for the analysis to reflect that. In this case, 0 equals "no presence of concern for harassment" and 1 equals "concern for at least one incident of harassment to occur."

Additional controls. I have included certain measures to describe respondents' demographic characteristics, with the intent to represent gender categories and religious group identification that affect one's likelihood of experiencing altruistic fear. Gender is measured with the responses: (1) male and (2) female. The male category serves as the reference category in the analysis. The religious identity category includes with the following responses: (1) Christian, all traditions, (2) Jewish, all traditions, (3) Muslim, all traditions, (4) Buddhist, (5) Hindu, (6) No religion, (7) Agnostic, (8) Atheist. Next, the analysis will control for variables that might impact one's personal and altruistic fears of being victimized. The control measures include race, age, marital status, and parental status. Age is represented by a continuous numerical value of selfreported age by respondents and responses range from 18 years old to 96 years old, with the mean age being 46 years old. The race category includes the following: (1) White, (2) Black, (3) Hispanic/Latino, (4) Middle Eastern, (5) East Asian, (6) South Asian, (7) Native American, (8) Pacific Islander, (9) Other, which includes multiracial identifications. Next, the parental status variable includes the categories (0) no kids and (1) has kids and is recoded from self-reported numerical responses asking respondents about the number of children they have. Lastly, marital status includes the responses (1) Married, (2) Living together, (3) Divorced, (4) Separated, (5) Widowed, and (6) Single. 


\section{Analysis}

This study will employ logit regression analyses to measure the effect of religious identity, visibility, and gender on altruistic fear. This method of analysis was chosen to determine what significant differences, if any, exist between religious groups in the U.S. and their altruistic fears of religious victimization. The model will include an interaction term of gender $\mathrm{x}$ religious identity to measure whether there is a significant interaction between the two in determining altruistic fear. This model chose to examine the effects before and after including marital and child status to better indicate where altruistic fear of the individual is being directed. The results will also include descriptive statistics and cross-tabulations of outcome measures related to both personal fears of religious victimization and altruistic fears of religious victimizations.

\section{Results}

Table 1 includes descriptive statistics of the response percentage for the main survey question measuring altruistic fear. This question asked how concerned the respondent was that someone they know personally will be threatened, harassed, or violently attacked because of their religion. While the majority of people across religious groups were either somewhat concerned or very concerned, there is a noticeable difference in percentages across the groups. Jewish and Muslim respondents were most altruistically fearful than Christian, Buddhist, Hindu, Non-religious, and other category respondents. $82.3 \%$ of Jewish respondents had some level of concern, compared to $54.1 \%$ of Christian respondents. Additionally, $27 \%$ of those Jewish respondents indicated that they were very concerned for their loved ones. The other group with the highest rate of altruistic fear were Muslims. About $88 \%$ had some level of concern, with $50 \%$ being very concerned of the possible harassment of someone they know personally. These 
statistics hint at the hypothesis that Muslims and Jews will have more altruistic fear overall than those of other religious or non-religious backgrounds.

\section{<TABLE 1>}

Table 2 shows descriptive statistics of the response percentage for the survey question asking respondents to identify how many people they know personally who have been victimized. This question is included in the analysis to better indicate whether altruistic fear for other is related to previous incidents of harassment of one's loved ones. Christians, Buddhists, Hindus, and No religion/atheists/agnostics overwhelmingly had no loved ones who were threatened, harassed, or violently attacked because of their religion. On the other hand, some of the more significant and interesting statistics show that $57 \%$ of Jewish respondents know at least one person who has been victimized, with $16 \%$ knowing four or more people who have been victimized. Also, $67 \%$ of Muslim respondents know at least one person who has been victimized, with $22 \%$ knowing four or more people. Because of the noticeable differences in rates of victimization of loved ones, these descriptive statistics might indicate and validate higher rates of altruistic fear among different religious groups. These results suggest that altruistic fear might be driven by one's past experiences with their friends and family being victimized based on their religious identities.

\section{<TABLE 2>}

Table 3 includes the response percentage for the previous survey questions by both religious tradition and gender. For most groups, it seems there is no obvious difference in level of concern/fearfulness by gender even though overall most people are more often concerned for others than they are not. However, Muslims and Hindus stand out in the stark difference between gender and fearfulness. Almost 100\% (99.2\%) of Muslim women have some level of concern for 
someone they know personally, while this is true for only $80 \%$ of Muslim men. For Hindu women, about $82 \%$ express having some level of concern, while only $53 \%$ of Hindu men feel the same. These descriptive statistics not only indicate that the original hypothesis about gendered differences in altruistic fear might not be relevant in relation to this analysis and religious victimization, but that the original hypothesized direction of fear might be reversed.

\section{$\langle$ TABLE 3>}

Next, my analysis includes a Pearson correlation coefficient table, which shows the strength and direction of the association between my dependent variable (altruistic fear) and my main independent variables of interest (actual victimization, personal fear of being victimized, and number of loved ones victimized). In this case, all variables are in their ordinal forms, rather than the binary form used for other analyses. In this analysis, I find that all of the measured correlations are statistically significant with either small or moderate levels of correlation with the dependent variable. For example, the association between altruistic fear and actual victimization is $r=0.20, \mathrm{p}<0.01$, which suggests that there is a small, positive correlation between the two. For the other independent variables, the results for both indicate a moderate, positive correlation with altruistic fear (personal fear, $r=0.35, \mathrm{p}<0.01$; number of loved ones victimized, $r=0.44, \mathrm{p}<0.01$ ). These results are all in the hypothesized directions, which means that an increase in actual victimization, personal fears, and having loved ones victimized are all correlated to an increase in altruistic fears of victimization.

\section{$<$ TABLE 4>}

Lastly, the multivariate analysis will expand on the patterns observed in the initial analysis mentioned above. Due to the binary nature of the outcome variable measuring altruistic fear $(0=$ not at all concerned, $1=$ at least some concern present $)$, I utilize logistic regression 
models to evaluate the independent associations between our predictors and altruistic fear. The results of these models are shown in Table 5. This table presents effects in the form of odds ratios, so that the values above one mean that the measure is associated with an increase in the odds of an individual having altruistic fear, while values below one mean that the measure is associated with a decrease in the odds of an individual having altruistic fear. The numbers in the parentheses represent the t-value for each odds ratio.

\section{<TABLE 5>}

Model 1 begins by including just gender and religious identity as the only predictors of altruistic fear. We find some strong associations with some minority religious identifications, in comparison to the reference group of Christians, and altruistic fear. First, we find that Jewish respondents are more likely than Christians to have concern of victimization for someone they know personally, thus exhibiting more altruistic fear $(o . r .=4.21, \mathrm{p}<0.01)$. The same is true for Muslim respondents compared to Christian respondents $($ o.r. $=7.29, \mathrm{p}<0.01)$ and a bit surprisingly and to a lesser extent, for Buddhists compared to Christians $($ o.r. $=1.65, \mathrm{p}<0.05)$. This is in line with our earlier observations of responses based on religious identity and is in line with hypotheses 2 and 3. However, model 1 also indicates that hypothesis 1 (about gender) may not apply. In this model, we find that female respondents of all religious identities are more likely than male respondents to have altruistic fear $($ o.r. $=1.53, \mathrm{p}<0.01)$.

Model 2 includes both gender and religious identity again but also adds the predictor of personal fear of victimization. We find that there is a strong association between altruistic fear and personal fear, where those who are personally fearful are more likely to be altruistically fearful as well $($ o.r. $=10.49, \mathrm{p}<0.01)$. Personal fear also seems to mediate the relationship 
between certain religious identities and altruistic fear, as the odds ratios decrease for Jewish and Muslim respondents with the addition of the personal fear predictor.

Model 3 adds the predictor of whether a respondent knows someone who has been victimized in the past due to their religious identity. We find the people who know someone who has been victimized are more likely than those who do not know someone who has been victimized to have altruistic fear $(o . r .=2.72, \mathrm{p}<0.01)$. Still, Jewish respondents and women compared to Christians and men are more likely to have altruistic fear with the introduction of these predictors in model 3.

Model 4 aims to test the hypothesis that indicates there is some interaction between religious identity and gender that could affect whether one is altruistically fearful. There is no significant differences within the interaction terms compared to Christian men besides the strong association of Muslim women and altruistic fear. The model indicates that Muslim women are almost 20 times more likely than Christian men to exhibit altruistic fear $(o . r .=19.76, \mathrm{p}<0.01)$. This is an important finding that suggests hypothesis 4 is not applicable and overall, women are more fearful for others, despite their own perceived vulnerability due to visibility. It's important to note that we do not necessarily know where or who the fear is directed towards (I.e. spouse, close friend, parents, or children), but for the purposes of this study, we are assuming the fear is primarily directed towards a spouse.

Model 5 begins to add in the remaining control variables including age, race, marital status, and parental status without the gender $\mathrm{x}$ religion interaction term. While the results are similar for each religious category to those in Model 4, the addition of the remaining control variables suggests some other demographic categories influence an individual's level of fear. In this model, we see that Black respondents across all religious categories are more likely than 
White respondents (the reference group) to be altruistically fearful $(o . r .=1.58, \mathrm{p}<0.01)$. It's interesting that the other race and ethnicity categories did not have any similar or statistically significant effect on one's fear, suggesting that race (particularly being Black) can slightly heighten one's level of altruistic fear.

Model 6 is the final model that includes all of our predictors and the interaction term and we find that Jewish respondents, Buddhist respondents, and female respondents still are significantly more likely to exhibit altruistic fear than others. Additionally, the "Muslim female" effect discovered in Model 4 is still large and statistically significant $(o . r .=18.20, \mathrm{p}<0.05)$. It seems across all models and categories that our hypotheses about gender does not apply and that women are more fearful for others, even if they are the more "visible" gender in their religious tradition.

\section{Discussion}

While some of the results align with previous research on altruistic fear, it's clear that fear of religious victimization might not present itself in the same way as other types of fear of crime. First, while some of the literature on altruistic fear and gender is mixed, previous literature typically indicates that men are more altruistically fearful than women. However, the results specifically related to the hypotheses regarding gender (hypotheses 1, 4, and 5) were not supported by the results of the regression analyses. Firstly, it seems that, across the board and across religious traditions, women are typically more altruistically fearful than men.

Additionally, the other hypotheses suggesting that the presumed more "religiously visible" gender would be less fearful for others was not supported and, in fact, we found the opposite effect. Particularly, holding all other variables constant, Muslim women were the most likely compared to Christian men to report having altruistic fear. Additionally, those who had been 
previously victimized themselves or know someone who had been victimized because of their religion were more likely than those who hadn't to be altruistically fearful. This suggests that previous incidents with victimization (whether personally or within one's circle) play a role in how fearful they will be for themselves and others. It seems that, not only is the fear justified because of actual occurrences of victimization, but that religious minority status can elevate that fear. For example, our regression analysis results indicate that there is somewhat of a "Jewish effect" in all of our models - where Jews are fearful for others despite our various controls and situations in place. This suggests that political climate, historical and current hostilities might influence one's level of fear for being victimized. This might also explain the increased altruistic fearfulness that Blacks across all religious traditions have compared to Whites, as well.

Overall, the results indicate that religious minorities in this country have a real fear for themselves and others of being victimized because of their religious identity. This altruistic fear is informed by past experiences, general hostility, visibility, and perceived vulnerability. To better understand these mechanisms of fear, more studies should be done to analyze the reality of religious victimization in the U.S and how different groups respond to potential risks and victimization. Particularly, altruistic fear studies would be an interesting point of inquiry, as previous research indicates that altruistic fear results in attitude and behavior changes. In my future research, I would like to delve into what those attitude and behavior changes actually are. Do the "vulnerable" groups choose to associate less with potential perpetrators? Do they stay home at night or avoid unfamiliar areas and situations? Have they bought protective gear for their houses and families? Clearly, we were not able to answer that in this study but I think future follow-up studies could answer these questions and provide insight into the reality of fear based on religious victimization. 


\section{Limitations}

One major limitation of this thesis is the availability of relevant questions and measures from the survey used for the analysis. Some of the connections of mechanisms of fear and direction of fear are assumptions based on previous literature, rather than known information provided by respondents. For example, we are assuming that women's altruistic fear is directed towards husbands and children, primarily, and vice versa for male respondents. The second limitation is about the assumption of religious visibility, which is informed by religious tradition, gender, and survey responses. Another limitation is the conflicts in previous literature about altruistic fear of crime and gender. It seems that there is not really a consensus on which gender is more fearful and that other factors might be at play when analyzing gendered differences. However, despite its limitations, this study has given us insight to a severely understudied area of criminological and sociological research - religious victimization and fear of crime in the U.S. Future studies should fill in the gaps with surveys and interviews designed specifically to address altruistic fear by asking questions focused on the subject of one's fear, religious visibility, past experiences of victimization, and resulting attitude and behavior changes as a result of the fear. 
TABLES

Table 1. Percent of respondents reporting altruistic fear (main dependent variable), by religious tradition.

$\begin{aligned} & \text { Regardless of whether it has happened in the past, how concerned are you that someone you know personally will be } \\
& \text { threatened, harassed, or violently attacked because of their religion? }\end{aligned}$
\begin{tabular}{l|ccccccc} 
& Christian & Jewish & Muslim & Buddhist & Hindu & No religion & Other \\
\hline Very concerned & $17.7 \%$ & $27.2 \%$ & $50.3 \%$ & $25.3 \%$ & $10.4 \%$ & $16.2 \%$ & $32.9 \%$ \\
Somewhat concerned & $36.4 \%$ & $55.1 \%$ & $38.0 \%$ & $40.1 \%$ & $54.1 \%$ & $40.9 \%$ & $39.1 \%$ \\
Not at all concerned & $45.9 \%$ & $17.7 \%$ & $11.7 \%$ & $34.6 \%$ & $35.5 \%$ & $42.9 \%$ & $28.0 \%$ \\
Total & $100 \%$ & $100 \%$ & $100 \%$ & $100 \%$ & $100 \%$ & $100 \%$ & $100 \%$ \\
$\mathrm{~N}$ & 1722 & 393 & 190 & 182 & 55 & 1865 & 250 \\
\hline
\end{tabular}

Table 2. Percent of respondents reporting knowing someone who has been victimized, by religious tradition.

Not counting yourself, how many people do you know personally who have been threatened, harassed, or violently attacked because of their religion?

\begin{tabular}{l|ccccccc}
\hline & Christian & Jewish & Muslim & Buddhist & Hindu & No religion & Other \\
\hline None & $70.1 \%$ & $43.0 \%$ & $33.0 \%$ & $64.4 \%$ & $78.3 \%$ & $66.0 \%$ & $42.6 \%$ \\
One & $7.9 \%$ & $11.6 \%$ & $8.2 \%$ & $8.6 \%$ & $5.6 \%$ & $11.3 \%$ & $17.2 \%$ \\
Two or three & $15.5 \%$ & $29.1 \%$ & $36.8 \%$ & $18.7 \%$ & $7.9 \%$ & $16.3 \%$ & $25.4 \%$ \\
Four or more & $6.5 \%$ & $16.3 \%$ & $22.0 \%$ & $8.3 \%$ & $8.2 \%$ & $6.4 \%$ & $14.8 \%$ \\
Total & $100 \%$ & $100 \%$ & $100 \%$ & $100 \%$ & $100 \%$ & $100 \%$ & $100 \%$ \\
$\mathrm{~N}$ & 1722 & 393 & 190 & 182 & 55 & 1865 & 250 \\
\hline
\end{tabular}


Table 3. Altruistic fear response percentage by religious tradition and gender.

Regardless of whether it has happened in the past, how concerned are you that someone you know personally will be threatened, harassed, or violently attacked because of their religion?

\begin{tabular}{|c|c|c|}
\hline & Male & Female \\
\hline \multicolumn{3}{|l|}{ Christian } \\
\hline Very concerned & $16.3 \%$ & $19.1 \%$ \\
\hline Somewhat concerned & $34.1 \%$ & $38.5 \%$ \\
\hline Not at all concerned & $49.6 \%$ & $42.4 \%$ \\
\hline Total & $100 \%$ & $100 \%$ \\
\hline \multicolumn{3}{|l|}{ Jewish } \\
\hline Very concerned & $28.3 \%$ & $26.2 \%$ \\
\hline Somewhat concerned & $55.2 \%$ & $54.9 \%$ \\
\hline Not at all concerned & $16.5 \%$ & $18.9 \%$ \\
\hline Total & $100 \%$ & $100 \%$ \\
\hline \multicolumn{3}{|l|}{ Muslim } \\
\hline Very concerned & $49.2 \%$ & $51.6 \%$ \\
\hline Somewhat concerned & $30.8 \%$ & $47.6 \%$ \\
\hline Not at all concerned & $20.0 \%$ & $0.8 \%$ \\
\hline Total & $100 \%$ & $100 \%$ \\
\hline \multicolumn{3}{|l|}{ Buddhist } \\
\hline Very concerned & $30.3 \%$ & $19.2 \%$ \\
\hline Somewhat concerned & $30.7 \%$ & $51.5 \%$ \\
\hline Not at all concerned & $39.0 \%$ & $29.3 \%$ \\
\hline Total & $100 \%$ & $100 \%$ \\
\hline \multicolumn{3}{|l|}{ Hindu } \\
\hline Very concerned & $11.6 \%$ & $8.7 \%$ \\
\hline Somewhat concerned & $41.0 \%$ & $73.1 \%$ \\
\hline Not at all concerned & $47.4 \%$ & $18.2 \%$ \\
\hline Total & $100 \%$ & $100 \%$ \\
\hline \multicolumn{3}{|l|}{ No religion } \\
\hline Very concerned & $12.8 \%$ & $20.5 \%$ \\
\hline Somewhat concerned & $39.5 \%$ & $42.5 \%$ \\
\hline Not at all concerned & $47.7 \%$ & $37.0 \%$ \\
\hline Total & $100 \%$ & $100 \%$ \\
\hline \multicolumn{3}{|l|}{ Other } \\
\hline Very concerned & $24.4 \%$ & $38.4 \%$ \\
\hline Somewhat concerned & $35.1 \%$ & $41.8 \%$ \\
\hline Not at all concerned & $40.5 \%$ & $19.8 \%$ \\
\hline Total & $100 \%$ & $100 \%$ \\
\hline
\end{tabular}


Table 4. Zero-order correlation coefficients among the measured variables.

\begin{tabular}{|l|cccc|}
\hline & 1 & 2 & 3 & 4 \\
\hline 1. Altruistic fear & 1 & & & \\
2. Actual victimization & $0.20^{*}$ & 1 & & \\
& & & & \\
3. Personal fear of victimization & $0.35^{*}$ & $0.40^{*}$ & 1 & \\
4. Number of loved ones victimized & $0.44^{*}$ & $0.40^{*}$ & $0.28^{*}$ & 1 \\
\hline
\end{tabular}

${ }^{*} \mathrm{p}<0.01$

Table 5. Logit Regression Models Predicting Altruistic Fear

\begin{tabular}{|c|c|c|c|c|c|c|}
\hline & Model 1 & Model 2 & Model 3 & Model 4 & Model 5 & Model 6 \\
\hline \multicolumn{7}{|l|}{ Religious Identity } \\
\hline Christian (ref.) & -- & -- & -- & -- & -- & -- \\
\hline Jewish & $\begin{array}{l}4.21 * * \\
(8.44)\end{array}$ & $\begin{array}{c}2.80 * * \\
(5.72)\end{array}$ & $\begin{array}{c}2.47 * * \\
(4.83)\end{array}$ & $\begin{array}{c}3.30 * * \\
(4.34)\end{array}$ & $\begin{array}{c}2.93 * * \\
(5.53)\end{array}$ & $\begin{array}{c}3.81 * * \\
(4.71)\end{array}$ \\
\hline Muslim & $\begin{array}{c}7.29 * * \\
(3.98)\end{array}$ & $\begin{array}{l}3.41 * * \\
(2.60)\end{array}$ & $\begin{array}{c}2.11 \\
(1.62)\end{array}$ & $\begin{array}{l}1.15 \\
(0.29)\end{array}$ & $\begin{array}{c}2.15 \\
(1.62)\end{array}$ & $\begin{array}{c}1.23 \\
(0.40)\end{array}$ \\
\hline Buddhist & $\begin{array}{l}1.65^{*} \\
(2.36)\end{array}$ & $\begin{array}{l}1.80 * * \\
(3.03)\end{array}$ & $\begin{array}{l}1.77 * * \\
(2.71)\end{array}$ & $\begin{array}{c}1.70- \\
(1.87)\end{array}$ & $\begin{array}{c}2.16^{* *} \\
(3.43)\end{array}$ & $\begin{array}{l}2.10^{*} \\
(2.52)\end{array}$ \\
\hline Hindu & $\begin{array}{c}1.56 \\
(1.08)\end{array}$ & $\begin{array}{c}1.53 \\
(1.00)\end{array}$ & $\begin{array}{c}1.95 \\
(1.47)\end{array}$ & $\begin{array}{l}1.25 \\
(0.39)\end{array}$ & $\begin{array}{c}2.08 \\
(1.17)\end{array}$ & $\begin{array}{c}1.30 \\
(0.35)\end{array}$ \\
\hline No religion & $\begin{array}{c}1.11 \\
(1.24)\end{array}$ & $\begin{array}{l}1.30 * * \\
(2.84)\end{array}$ & $\begin{array}{l}1.26- \\
(2.41)\end{array}$ & $\begin{array}{l}1.34^{*} \\
(2.16)\end{array}$ & $\begin{array}{c}1.17 \\
(1.52)\end{array}$ & $\begin{array}{c}1.25 \\
(1.61)\end{array}$ \\
\hline Other religion & $\begin{array}{c}2.11 * * \\
(4.09)\end{array}$ & $\begin{array}{c}1.88 * * \\
(3.06)\end{array}$ & $\begin{array}{c}1.37 \\
(1.29)\end{array}$ & $\begin{array}{c}0.85 \\
(-0.36)\end{array}$ & $\begin{array}{c}1.45 \\
(1.54)\end{array}$ & $\begin{array}{c}0.90 \\
(-0.24)\end{array}$ \\
\hline Female $($ ref. $=$ Male $)$ & $\begin{array}{l}1.53 * * \\
(4.84)\end{array}$ & $\begin{array}{c}1.64 * * \\
(5.36)\end{array}$ & $\begin{array}{l}1.81 * * \\
(5.81)\end{array}$ & $\begin{array}{c}1.76^{* * *} \\
(4.03)\end{array}$ & $\begin{array}{l}1.84 * * \\
(5.88)\end{array}$ & $\begin{array}{c}1.80 * * \\
(4.12)\end{array}$ \\
\hline Personal Fear of Victimization & -- & $\begin{array}{c}10.49 * * \\
(3.09)\end{array}$ & $\begin{array}{l}7.48^{* * *} \\
(7.22)\end{array}$ & $\begin{array}{c}7.49 * * \\
(7.43)\end{array}$ & $\begin{array}{c}7.86^{* * *} \\
(7.13)\end{array}$ & $\begin{array}{c}7.89 * * \\
(7.30)\end{array}$ \\
\hline Know Someone Victimized & -- & -- & $\begin{array}{l}2.72 * * \\
(11.68)\end{array}$ & $\begin{array}{l}2.74 * * \\
(11.59)\end{array}$ & $\begin{array}{l}2.71 * * \\
(11.78)\end{array}$ & $\begin{array}{l}2.72 * * \\
(11.73)\end{array}$ \\
\hline Actual Personal Victimization & -- & -- & -- & -- & $\begin{array}{c}0.87 \\
(-1.07)\end{array}$ & $\begin{array}{c}0.87 \\
(-1.08)\end{array}$ \\
\hline
\end{tabular}


Religion X Gender Interaction Term (ref.

$=$ Christian, Male)

Jewish X Female

\begin{tabular}{|c|c|c|c|c|c|}
\hline -- & -- & -- & $\begin{array}{c}0.55 \\
(-1.66)\end{array}$ & -- & $\begin{array}{c}0.58 \\
(-1.47)\end{array}$ \\
\hline -- & -- & -- & $\begin{array}{c}19.76 * * \\
(2.88)\end{array}$ & -- & $\begin{array}{l}18.20 * \\
(2.53)\end{array}$ \\
\hline -- & -- & -- & $\begin{array}{c}1.08 \\
(0.19)\end{array}$ & -- & $\begin{array}{c}1.08 \\
(0.17)\end{array}$ \\
\hline -- & -- & -- & $\begin{array}{c}3.13 \\
(1.24)\end{array}$ & -- & $\begin{array}{c}3.25 \\
(1.21)\end{array}$ \\
\hline -- & -- & -- & $\begin{array}{c}0.85 \\
(-0.85)\end{array}$ & -- & $\begin{array}{c}0.84 \\
(-0.89)\end{array}$ \\
\hline -- & -- & -- & $\begin{array}{c}2.27 \\
(1.59)\end{array}$ & -- & $\begin{array}{c}2.28 \\
(1.58)\end{array}$ \\
\hline & & & & $\begin{array}{l}0.98 * * \\
(-4.24)\end{array}$ & $\begin{array}{l}0.98 * * \\
(-4.23)\end{array}$ \\
\hline
\end{tabular}

Muslim X Female

Buddhist X Female

Hindu X Female

No religion X Female

Other religion $\mathrm{X}$ Female

Age

Race

White (ref.)

Black

Hispanic/Latino

Middle Eastern

East Asian

South Asian

Native American

Pacific Islander

Other

Parental Status

$--$

Marital Status 


\begin{tabular}{|c|c|c|c|c|c|c|}
\hline Married (ref.) & -- & -- & -- & -- & -- & -- \\
\hline Living together & -- & -- & -- & -- & $\begin{array}{c}0.72 \\
(-1.56)\end{array}$ & $\begin{array}{c}0.71 \\
(-1.55)\end{array}$ \\
\hline Divorced & -- & -- & -- & -- & $\begin{array}{c}0.92 \\
(-0.42)\end{array}$ & $\begin{array}{c}0.92 \\
(-0.41)\end{array}$ \\
\hline Separated & -- & -- & -- & -- & $\begin{array}{c}0.48 \\
(-1.61)\end{array}$ & $\begin{array}{c}0.48 \\
(-1.64)\end{array}$ \\
\hline Widowed & -- & -- & -- & -- & $\begin{array}{c}1.03 \\
(0.10)\end{array}$ & $\begin{array}{c}1.02 \\
(0.07)\end{array}$ \\
\hline Single & -- & -- & -- & -- & $\begin{array}{c}0.74^{*} \\
(-2.10)\end{array}$ & $\begin{array}{c}0.74^{*} \\
(-2.09)\end{array}$ \\
\hline Intercept & $\begin{array}{c}0.989 \\
(-0.14)\end{array}$ & $\begin{array}{c}0.058 * * \\
(-8.51)\end{array}$ & $\begin{array}{l}0.018 * * \\
(-11.87)\end{array}$ & $\begin{array}{l}0.019 * * \\
(-11.74)\end{array}$ & $\begin{array}{c}0.045 * * \\
(-8.12)\end{array}$ & $\begin{array}{c}0.045^{* *} \\
(-8.07)\end{array}$ \\
\hline
\end{tabular}

Odds ratios reported; $\mathrm{N}=4482 ; * * \mathrm{P}<0.01,{ }^{*} \mathrm{P}<0.05$ 


\section{References}

Abu-Ras, W. M., \& Suarez, Z. E. 2009. "Muslim men and women's perception of discrimination, hate crimes, and PTSD symptoms post 9/11." Traumatology 15(3): 48-63.

Ardley, J. 2005. "Hate Crimes: A brief review." International Journal of Sociology and Social Policy 25(12): 54-66.

Biles, J, et al. 2002. "Testing 'the Canadian diversity model': hate, bias and fear after September $11^{\text {th }}$." Canadian Issues 54-58.

Byers, B, et al. 2007. "The Impact of the Terrorist Attacks of 9/11 on Anti-Islamic Hate Crime." Journal of Ethnicity in Criminal Justice 5(1): 43-56.

Chongatera, Godfred. 2013. "Hate-Crime Victimization and Fear of Hate Crime among Racially Visible People in Canada: The Role of Income as a Mediating Factor." Journal of Immigrant \& Refugee Studies 11(1):44-64.

Cook, C \& Fox, K. 2011. "Fear of Property Crime: Examining the Effects of Victimization, Vicarious Victimization, and Perceived Risk." Violence and victims 26: 684-700.

Craig, K. M. 1999. "Retaliation, Fear, or Rage: An Investigation of African American and White Reactions to Racist Hate Crimes." Journal of Interpersonal Violence, 14(2), 138-151.

Disha, Ilir, James C. Cavendish and Ryan D. King. 2011. "Historical Events and Spaces of Hate: Hate Crimes Against Arabs and Muslims in Post-9/11 America." Social Problems 58(1):21-46.

Disha, Ilir. 2005. "Location and Patterns of Anti-Arab and Anti-Muslim Hate Crimes." Southern Sociological Society.

Drakulich, K. 2014. "Concerns for self or family? Sources of and responses to altruistic fear." Journal of Interpersonal Violence 30(7): 1168-1207.

Dunbar, Edward. 2006. "Race, Gender, and Sexual Orientation in Hate Crime Victimization: Identity Politics Or Identity Risk?" Violence and Victims 21(3):323-37.

Farrall, S., Bannister, J. Ditton, J. and Gilchrist, E. 2000. "Social Psychology and the Fear of Crime; Re-Examining a Speculative Model.” The British Journal of Criminology 40(3): 399-413.

FBI. Hate Crime Statistics. 2019.

Ferarro, K. 1995. Fear of Crime: Interpreting Victimization Risk. Albany: State of New York Press.

Fox, C., \& Asquith, N. L. 2018. "Measuring the Tangible Fear of Heterosexist Violence." Journal of Interpersonal Violence 33(6): 980-1007.

Frost, Diane. 2008. "Islamophobia: Examining Causal Links between the Media and "Race Hate" from "Below"." The International Journal of Sociology and Social Policy 28(11):564-578.

Gainey, et al. 2011. "Fear of Crime Revisited: Examining the Direct and Indirect Effects of Disorder, Risk Perception, and Social Capital.” American Journal of Criminal Justice 36: 120-137.

Garnets, L., Herek, G. M., \& Levy, B. 1992. "Violence and victimization of lesbians and gay men: Mental health consequences." Hate crimes: Confronting violence against lesbians and gay men. 207-226.

Gladfelter, A., Lantz, B., \& Ruback, B. 2017. 'The complexity of hate crime and bias activity: Variation across contexts and types of bias.' Justice Quarterly 34(1): 55-83.

Gramlich, John. 2017. "Voters' perceptions of crime continue to conflict with reality." Pew Research Center.

Green, D., McFalls, L., \& Smith, J. 2001. “Hate crime: An emergent research agenda.” Annual Review of Sociology 27(1): 497-504.

Grim, B., \& Finke, R. 2007. "Religious Persecution in Cross-National Context: Clashing Civilizations or Regulated Religious Economies?” American Sociological Review 72(4): 633658. 
Haddad, Y. 2007. "Post 9/11 Hijab as Icon.” Sociology of Religion 68(3): 253-267.

Hale, C. 1996. Fear of Crime: A Review of the Literature. International Review of Victimology 4: 79150.

Herek, Gregory \& Gillis, Joseph Roy \& Cogan, Jeanine. 2000. "Psychological sequelae of hate-crime victimization among lesbian, gay, and bisexual adults." Journal of consulting and clinical psychology.

Howell, Frank M., John P. Bartkowski, Lynn M. Hempel and Jeremy R. Porter. 2018. "When Faith, Race, and Hate Collide: Religious Ecology, Local Hate Cultures, and Church Burnings." Review of Religious Research 60(2):223-245.

Iganski, P. 2001. "Hate Crimes Hurt More.” American Behavioral Scientist 45(4): 626-638.

Iwama, Janice A. 2018. "Understanding Hate Crimes Against Immigrants: Considerations for Future Research." Sociology Compass 12(3).

Jackson, J. 2007. 'Revisiting Vulnerability in the Fear of Crime: Gender, Age and the Psychology of Risk.'

Jackson, J. 2008. "Briding the social and the psychological in the fear of crime." Fear of crime: critical voice in an age of anxiety. Abingdon, UK. GlassHouse Press:143-167.

Javaid, A. 2019. "The Haunting of Hate: Rape as a Form of Hate Crime." Sexuality \& Culture 24: 573-595.

Jenkins, P. 1992. Intimate Enemies. New York: Aldine de Gruyter.

Killias, M. 1990. "Vulnerability: Towards a Better Understanding of a Key Variable in the Genesis of Fear of Crime.' Violence and Victims 5 (2): 97-108.

Lawrence, F. M. 1999. Punishing hate. Cambridge, MA: Harvard University Press.

Levin, J. \& Rabrenovic, G. 2001. "Hate Crimes and Ethnic Conflict: An Introduction.” American Behavioral Scientist 45(4):574-587.

Lyons, C. 2008. "Defending Turf: Racial Demographics and Hate Crime Against Blacks and Whites." Social Forces 87(1).

Maguire, K. and Pastore, A. 1997. Sourcebook of Criminal Justice Statistics. U.S. Department of Justice. Washington, DC.

May, D. C. 2001. "The effect of fear of sexual victimization on adolescent fear of crime." Sociological Spectrum 21: 141-174.

McDevitt, J., Levin, J. and Bennett, S. 2002. "Hate Crime Offenders: An Expanded Typology." Journal of Social Issues 58: 303-317.

Messner, S. F., McHugh, S., \& Felson, R. B. 2004. "Distinctive characteristics of assaults motivated by bias." Criminology 42(3): 585-618.

Morsch, J. 1991. The Problem of Motive in Hate Crimes: The Argument against Presumptions of Racial Motivation." Journal of Criminal Law and Crimonology 82(3).

Naderi, Pooya. 2018. "Non-threatening Muslim Men: Stigma Management and Religious Observance in America." Qualitative Sociology

Nelson, Matthew S., Alese Wooditch, Favian A. Martin, Don Hummer and Shaun L. Gabbidon. 2016. "Hate Crimes in Post-9/11 Pennsylvania." Race and Justice 6(4):303-324.

O’Brien, R. 1995. "Crime and Victimization Data." Criminology: A Contemporary Handbook." New York: Wadsworth.

Pain, R. 2000. "Place, social relations and the fear of crime: a review." Progress in Human Geography, 24(3), 365-387.

Perry, B. 2002. "Hate crime and identity politics." Theoretical Criminology 6(4): 485-491. 
Pew Research Center. 2017. "Americans Express Increasingly Warm Feelings Toward Religious Groups.” Pewresearch.org.

Piatkowska, Sylwia J., Steven F. Messner and Tse-Chuan Yang. 2019. "Understanding the Relationship between Relative Group Size and Hate Crime Rates: Linking Methods with Concepts." Justice Quarterly : JQ 36(6):1072-1095.

Rader, N. E., Cossman, J. S., Allison, M. 2009. "Considering the gendered nature of constrained behavior practices among male and female college students." Journal of Contemporary Criminal Justice 25:282-299.

Scheitle, Christopher P., and Michelle Hansmann. 2016. "Religion-Related Hate Crimes: Data, Trends, and Limitations." Journal for the Scientific Study of Religion 55(4):859-873.

Scheitle, Christopher P. 2018. "Religious Congregations' Experiences with, Fears of, and Preparations for Crime: Results from a National Survey." Review of Religious Research 60(1): 95-113.

Singer, et al. 2019. "Victimization, Fear of Crime, and Trust in Criminal Justice Institutions:

A Cross-National Analysis." Crime and Delinquency 65(6): 822-844.

Skogan and Maxfield. 1981. Coping with Crime: Individual and Neighborhood Reactions. SAGE Publications.

Snedker, K. A. 2006. "Altruistic and vicarious fear of crime: Fear for others and gendered social roles." Sociological Forum 21(2):163-195.

Soni, Sharad K. 2013. "Gauging the Implications of the Wisconsin Sikh Temple Shooting." Asian Ethnicity 14(1):106-109.

Sparks, R. 1992. 'Reason and unreason in left realism: some problems in the constitution of the fear of crime', in: Matthews, R. and J.Young, J. (Eds) Issues in Realist Criminology, London: Sage.

Stewart-Williams, S. 2007. "Altruism among kin vs. nonkin: effects of cost of help and reciprocal exchange." Evolution and Human Behavior 28: 193-198.

Stotzer, Rebecca L. 2008. "Gender Identity and Hate Crimes: Violence Against Transgender People in Los Angeles County." Sexuality Research and Social Policy: Journal of NSRC 5(1):43-52.

Sweet, J. and Bumpass, L. 1990. American Families and Households. New York: Russell Sage Foundation.

Thompson, P. \& Dean, W. 1996. Competing conceptions of risk. Science and Engineering. Ethics 5(4): 489-510.

Trickett, L. 2009. “'Don't Look Now' : Masculinities, Altruistic Fear, and the Spectre of Self: when, why, and how men fear for others." Crimes and Misdemeanours 3(1): 82-108.

Van der Wurff, A., Van Staalduinen, L., and Stringer, P. 1989. "Fear of Crime in Residential Environments: Testing a Social Psychological Model.” Journal of Social Psychology 129(2):141-160.

Walfield, Scott M., Kelly M. Socia and Rá Powers. 2017. "Religious Motivated Hate Crimes: Reporting to Law Enforcement and Case Outcomes." American Journal of Criminal Justice: AJCJ 42(1):148-169.

Warr, M. 1992. "Altruistic fear of victimization in households.” Social Science Quarterly. 73: 723736.

Warr, M. 1994. "Public perceptions and reactions to violent offending and victimization." In A. J. Reiss, Jr., J. A. Roth (Eds.) \& National Research Council, Understanding and preventing violence, Vol. 4. Consequences and control (p. 1-66). National Academy Press.

Warr, M. 2000. "Rethinking Social Reactions to Crime: Personal and Altruistic Fear in Family Households.” American Journal of Sociology. 106(3):551-578. 
Wu, Y., Wen, J. 2014. "Fear of crime among Chinese immigrants in Metro-Detroit." Crime Law Soc Change 61: 495-515.

Zaykowski, Heather. 2010. "Racial Disparities in Hate Crime Reporting." Violence and victims. 25: 378-94. 